\title{
Bland vita, svarta och grå "svanar" i det reformerade svenska pensionssystemet
}

\author{
Lars Harrysson \& Erika Werner
}

SAMMANDRAG: Det reformerade allmänna svenska pensionssystemet har hyllats av många, inte minst av dem som deltagit i själva utarbetandet av systemet, men hur upplevs några av de mer grundläggande antagandena bakom reformen av dem det avser att ge ekonomiskt skydd åt på ålderdomen? Genom ett omfattande djupintervjumaterial visar Lars Harrysson och Erika Werner att det finns såväl stöd som brist på det samma för dessa antaganden. Bland annat på frågorna om viljan och förmågan att välja själv bland pensionsfonder, och om en adekvat pension kan förväntas, ges övervägande ett ganska svagt stöd, men det finns också tydliga undantag. Mycket talar för att lovsången till pensionssystemet bör tystna, åtminstone till hur utformningen av systemet ser ut i dag, inte till reformen i sig. Den var nödvändig.

NYCKELORD: det svenska pensionssystemet; pensionsreform; allmän pension; ålderspension; socialförsäkringar; pensionering; styrningskonst (gouvernementalité).

PUBLICERINGSHISTORIK: Originalpublicering.

LARS HARRYSSON är lektor i socialt arbete vid Lunds universitet.

E-POSTADRESS: lars.harrysson@soch.lu.se

ERIKA WERNER är lektor i socialt arbete vid Lunds universitet.

E-POSTADRESS: erika.werner@soch.lu.se

FÖRSLAG PÅ KÄLLANGIVELSE:

Harrysson, Lars \& Erika Werner (2014) "Bland vita, svarta och grå 'svanar' i det reformerade svenska pensionssystemet", i Arkiv. Tidskrift för sambällsanalys, nr 3, s. 7-37. DoI: http://dx.doi.org/I0.I3068/2000-6217.3.I

(C) Författarna/Arkiv förlag \& tidskrift 2014 (publicerad 24 oktober 20I4)

Artikeln distribueras enligt en upphovsrättslicens från Creative Commons: Erkännande-Ickekommersiell-IngaBearbetningar 3.o Unported, som medger fri ickekommersiell användning och spridning i oförändrat skick så länge källan anges. 
Arkiv. Tidskrift för samhällsanalys är en sakkunniggranskad vetenskaplig tidskrift för samhällsvetenskap och historia. Samtliga artiklar publiceras fritt tillgängliga på:

www.tidskriftenarkiv.se

(beständig länk, DoI: http://dx.doi.org/IO.I3068/2000-62I7)

Den här artikeln finns tillgänglig i följande format:

PDF \& HTML: via beständig länk, DOI: http://dx.doi.org/IO.I3068/2000-62I7.3.I EPUB: ingår i e-boksutgåva av numret, ISBN: 978 9I 79242657

TRYCK: ingår i bokutgåva av numret, ISBN: 978 9I 79242664

Grafisk utformning och sidnumrering är identisk i pdf och tryck.

Samtliga artiklar i nr 3 (20I4) nås via beständig länk, DOI: http://dx.doi.org/I0.13068/2000-6217.3

Arkiv. Tidskrift för sambällsanalys ISSN: 2000-62I7 (för elektronisk resurs)

ISSN: 2000-6225 (för tryckta nummer)

ges ut av

Stiftelsen Arkiv för främjande och spridning av samhällsvetenskaplig och historisk forskning

genom

Arkiv förlag \& tidskrift

Box 1559

SE-22I OI Lund

ВESÖK: L Gråbrödersg 3 c, ipg

TEL: O46-I3 3920

ARKIV FÖRLAG: arkiv@arkiv.nu·www.arkiv.nu

TIDSKRIFTEN ARKIV: red@tidskriftenarkiv.se · www.tidskriftenarkiv.se

ANSVARIg UTGIVARE \& CHEFREDAKTÖR: Sven Hort

ADMINistrativ RedAKTÖr: David Lindberg

ReDAKTörer: Paavo Bergman, Lisa Kings, Zhanna Kravchenko 


\section{Bland vita, svarta och grå "svanar" i det reformerade svenska pensionssystemet}

\section{LARS HARRYSSON \& ERIKA WERNER}

Vår artikel handlar om mötet mellan politik och människa. I vårt fall mötet mellan intentionerna bakom Sveriges allmänna pensionssystem och de försäkrades upplevelser av det. Det allmänna pensionssystemet har reformerats och förändringarna infördes stegvis från år 1999. Det har utvecklats från att vara ett uttalat kollektivt åtagande till ett markant individuellt risktagande. Detta gestaltar sig bland annat i den införda livsinkomstprincipen och att den försäkrade uppmuntras göra val i pensionssystemets premiedel. Tack vare systemets fonderade del har svenskarna blivit världens mest fondsparande folk (Strandberg 20Io), en företeelse som på ytan kan se ut som att förberedelserna varit goda och att människor gör de val systemets konstruktörer haft i åtanke. Samtidigt visar forskning att det svenska folkets förtroende för pensionssystemet sjunker (Svallfors 2003; 20II). I mars 20I4, efter att systemet varit i funktion i femton år, lämnade Pensionsgruppen ${ }^{\mathrm{I}}$ sin överenskommelse med förslag till vissa förändringar, bland annat att se över inkomstpensionernas utveckling, AP-fonderna och premiepensionen, samt åtgärder för att förlänga deltagandet $\mathrm{i}$ arbetslivet.

I. Pensionsgruppen är en parlamentarisk grupp tillsatt av Socialdepartementet och består av representanter från S, M, FP, C och KD. I och med Miljöpartiets regeringsöverenskommelse med Socialdemokraterna efter riksdagsvalet 20I4 har även MP accepterat den nuvarande pensionsuppgörelsen och kommer att ansluta till Pensionsgruppen. Överenskommelsen den I2 mars 2014 kan hämtas från http://www.regeringen.se/ content/I/c6/23/59/69/ob374372.pdf. 
Vår artikel tar avstamp i det förslag till reformerat pensionssystem som presenterades av Pensionsarbetsgruppen 1994. Gruppen, med samma parlamentariska sammansättning som Pensionsgruppen ovan, hade i uppgift att göra upp om ett nytt pensionssystem samt om dess införande. Vi formulerar och diskuterar fyra teser som är grundläggande för argumenten bakom konstruktionen av det nuvarande pensionssystemet, det vill säga till vad systemet reformerats. ${ }^{2}$

I. I det reformerade pensionssystemet upplever de försäkrade att de tillförsäkras en adekvat framtida pensionsinkomst.

2. I det reformerade pensionssystemet upplever de försäkrade sig förstå hur det skydd de garanteras av staten påverkar dem.

3a. I det reformerade pensionssystemet upplever de försäkrade sig ha större inflytande över sin framtida pensionsinkomst.

3b. I det reformerade pensionssystemet upplever de försäkrade ett ökat intresse för att välja hur de ska placera sina sparmedel.

Vår diskussion handlar inte om ifall det tidigare systemet behövde förändras. Där uppfattar vi att bilden ganska entydigt pekar på att så var fallet, inte minst till följd av de mängder små justeringar som gjordes i systemet genom åren (så kallad inkrementalism), vilka inte alltid stärkte vare sig systemet eller det långsiktiga skyddet för de försäkrade.

$\mathrm{Vi}$ vill snarare belysa och ge utrymme för människors resonemang kring pensionssystemets konstruktion och hur de grunder systemet vilar på upplevs av de försäkrade, det vill säga dem som systemet berör i sina konsekvenser: pensionsmottagarna. ${ }^{3}$

2. Argumenten utvecklas längre fram under respektive tes. Kapitel 6 i Pensionsarbetsgruppens betänkande, SOU 1994:20, redogör för principerna bakom deras förslag. Även på andra platser finns tydliga kopplingar till teserna. Tes I: s. I43, I5I-I52, I56, I62; tes 2: s. I42-I43; tes 3a: s. I46, I53, I58, I60; tes 3b: s. I47, I53, I58, I60. Vidare går det att läsa utdrag i 1997 års premiereservutrednings betänkande, SOU I997:I3I, som ger insikter kring de olika teserna. Tes 2: s. 55; tes 3a: s. 53, 77, 79, I08; tes 3 b: s. $67 \mathrm{f}$.

3. Till grund för vår undersökning ligger ett omfattande intervjumaterial. Delar av materialet, intervjuer genomförda 2005-20I2 med 78 personer födda mellan I93I-I98I, har tidigare använts i Harrysson \& Werner 2007, samt mer utförligt i Werner 20I2. Utöver detta har vi använt samtal med en person ur ett nytt intervjumaterial om 30 personer insamlat under 20I4, vilket är under fortsatt bearbetning. 


\section{Om svanarna}

Titeln på vår artikel introducerar en vacker fågel, svanen, vilken i den framförvarande texten kommer att fungera som metaforisk illustration av hur människors berättelser om och kring pensioner förhåller sig till de ovan presenterade teserna. Valet av svanen som illustration hänger samman med Karl Poppers klassiska falsifieringsexempel om att tesen "alla svanar är vita" är korrekt tills vi finner en svart svan. ${ }^{4} \mathrm{Vi}$ ämnar med svanmetaforen synliggöra stödet, eller bristen på stöd, för respektive tes utifrån intervjuade personers erfarenheter. Ju mörkare svan desto mindre stöd.

Kan man göra så här? Går det att värdera politiska intentioner utifrån enskildas upplevelser av konsekvenserna av de system som utvecklats ur dem?

$\mathrm{Vi}$ anser att tillvägagångssättet är belysande och lockar till eftertanke. Det är visserligen svårt att utan att mäta styrkan i en kritik hävda dess betydelse, men vår ambition är att peka på existensen av erfarenheter som kan ligga till grund för systemkritik och även ifrågasättande av de grundläggande intentioner som systemet vilar på. Utvecklingen och införandet av det reformerade pensionssystemet har kantats av stängda rum $\mathrm{i}$ kompromissens namn, självgodhet bland deltagarna och outtalade ideologiska föreställningar bakom politiska ställningstaganden och expertutlåtanden (Palme 200I; Lundberg 2003; Scherman 2014). Det som är speciellt vad gäller pensioner är att utfallet kommer först långt fram i tiden. Det gör det svårt för oss vanliga dödliga att bedöma konsekvenserna av ett tekniskt komplicerat system innan vi erfar dem. Inte blev det lättare av att kritiken av förslagen till stor del förbisågs, till exempel genom ett tidigt ställningstagande om att en pensionsavgiftshöjning för att klara den tillfälliga fyrtiotalistpuckeln inte var att tänka på. Vi talar alltså egentligen om ett systemskifte i reformförklädnad, en individualiseringsprocess som rimligen bör kunna belysas utifrån de berörda individernas upplevelser av den.

4. Se t.ex. Liedman 200I, s. I39 ff, eller Chalmers 1999, speciellt kapitel 5-7. Vi gör inga anspråk på en djupare vetenskapsteoretisk koppling till falsifikationismen än så i detta sammanhang. 
I de följande testen presenterar vi såväl empiriskt stöd för teserna som emot dem. Inför varje test diskuterar vi inledningsvis den berörda tesen lite närmare.

\section{Tes I}

I det reformerade pensionssystemet upplever de försäkrade att de tillförsäkras en adekvat framtida pensionsinkomst.

Den första tesen hämtas från ett av de mest grundläggande argumenten för reformeringen av pensionssystemet, nämligen att systemförändringen skulle generera stabilitet över tid och därmed pensionsinkomster för generationer framöver. Det argumenterades för att det närmaste man kan komma en sådan försäkran är att minska generationsöverföringarna i systemet. Livsinkomstprincipen kombinerad med snäva pensionskohorter (generationer) inom vilka inkomster omfördelas handlar i grunden om att minska utrymmet för att belasta kommande generationer med för stora nutida uttag. Att blockera en form av generationslån utan täckning bortom förväntad tillväxt, kan man säga. Uppfattningen om att detta är rätt väg bygger bland annat på antagandet att personer med samma ålder (antal möjliga intjänandeår) har mer gemensamt än om det avgörs på andra kriterier, till exempel yrkes- och klassbakgrund, kön och

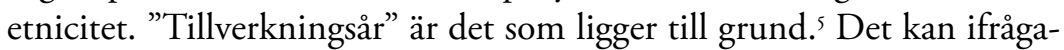
sättas om just detta är det mest avgörande för att skapa stabilitet, vilket är en fråga vi ber att få återkomma till i ett annat sammanhang. ${ }^{6}$

Frågan om vad som är en adekvat inkomst efter utträdet från arbetsmarknaden och som en följd av ålderpensionering är inte självklar. Vem anstår rätten att avgöra vad adekvat inkomst är? Vem har förmågan att avgöra det?? Ett sätt är att ställa det i relation till förväntad konsumtion

5. Sir Ken Robinsons beskrivning av skolsystemets löpande-band-princip baserat på just ålder är ett intressant exempel på en liknande problematik. Se en animerad version av hans föredrag "Changing Education Paradigms" för RSA (Royal Society for the encouragement of Arts, Manufactures and Commerce) från 2010 på https://www.youtube.com/ watch?v=zDZFcDGpL4U.

6. Vi önskar dock kort peka på att livslängden inte ökar för alla grupper! Se Klepke 20I3. 7. I sin avhandling diskuterar Daniel Bjerstedt rättigheter som en dynamisk process (2009, s. $52 \mathrm{ff}$ ). 
bland pensionärer i Sverige, det vill säga en samhällsnorm. Detta kan sägas ha varit modellen för det tidigare systemet, som levde i symbios med en ambition om minskade inkomstskillnader och därmed också strävade efter mer jämlika konsumtionsmöjligheter för pensionärer. ${ }^{8}$ Med stora inkomstskillnader fram till pensionen blir detta mer komplicerat eftersom acceptansen för skillnader före inte enkelt motiveras omvänt efter pensioneringen. ${ }^{9}$ I ett samhälle med accepterat växande inkomstojämlikhet ${ }^{10}$ krävs ett pensionssystem som minimerar fokus på det. Lösningen är ökad individualisering, eller som det heter i pensionssystemet, livsinkomstprincipen samt valfrihet i premiepensionen (PPM). Ambitionerna om att med hjälp av pensionssystemet göra vissa omfördelningar mellan inkomstgrupper minskades. Den tidigare arbetsgivaravgiftsfinansierade folkpensionen ersattes av en statsbudgetfinansierad utfyllnadspension (garantipensionen), medan pensionssystemet renodlades till ett avgiftsbestämt åldersskydd. ${ }^{\text {II }}$

Frågan om adekvat inkomst styrs dessutom av en ytterligare stabiliseringsprincip där de två argumenten ovan smälter samman i den så kallade balanseringen som med viss automatik förändrar nivån på utbetalade pensioner i relation till den samhällsekonomiska utvecklingen mätt enligt vissa kriterier: reallöneutvecklingen (löner i relation till priser) för inkomstpensionen och prisutvecklingen för garantipensionen. Systemet skyddar således inte de försäkrades kortsiktiga konsumtion utan sin egen existens. Så även om det finns en grundläggande idé om vad en adekvat pensionsinkomst är så är den inte en riktlinje för systemets funktion, utan däri ligger systemets egen långsiktiga stabilitet. ${ }^{12}$ Och om man som

8. Se t.ex. Amartya Sens Inequality reexamined där frågan om jämlikhet diskuteras utifrån olika sätt att hänföra till effekten av att studera eller mäta själva möjligheten att välja eller det som väljs (Sen I992, s. 34-35).

9. I det gamla ATP-systemet närmade sig många försäkrade taket, det vill säga pensionen blev alltmer en typ av enhetspension.

Io. Tapio Salonen ger en bild av inkomstojämlikheten i Sverige i rapporten Barns ekonomiska utsatthet från Rädda barnen (Salonen 20I2). Se även Wilkinson \& Pickett 2010. II. Dagens pensionssystem är ett fördelningssystem, det vill säga dagens inbetalade pensionsavgifter finansierar dagens utbetalda pensioner. Avgiftsbestämningen rör hur pensionsrätterna beräknas. Premiepensionen är fonderad.

I2. Det är viktigt att detta inte läses som en negativ kritik, utan som ett konstaterande. Det är givetvis en nödvändighet att ett system finns om det ska kunna ge några som helst pensionslöften. Om "robust" kan läsas i SOU I994:20, s. 156. 
försäkrad i systemet inte upplever sig ha tillräcklig kunskap kan systemet i sig upplevas som svårbegripligt och till och med orättvist. Undersköterskan Beata, en svart svan, var vid intervjun i 55-årsåldern. Hon hade på grund av sjukdom arbetat deltid under lång tid. Hon blev konfunderad när hon granskade sin pensionsinformation:

Jag och väninnorna vi ringer till varandra: "och jag har jobbat heltid och du har jobbat deltid", det var en av mina kompisar, " och vi har samma summor", och det kan inte hon förstå. Hon har jobbat heltid alltid. Det är ju väldigt konstigt och jag har jobbat deltid i så många år. Vi har samma summor. Det skiljer kanske en hundralapp! Det kan inte vara kul ... Nä ... Hon har alltid jobbat heltid. [...] Hon är född 53 ... och hon är med bara i det nya systemet och jag är med i båda två, jag är ju född 5r. Men det ska ju inte påverka tycker man?

Anette Nyqvist har i sin avhandling bland annat intervjuat medlemmar i Pensionsarbetsgruppen, en av dem förklarar den eftersträvade systemstabiliteten med att den är "synonym med att överföra alla risker till de försäkrade. Och det var huvudidén, poängen med det" (Nyqvist 2008, s. 83, vår övers.). Det är tydligt att stabiliteten i konstruktionen innebär ett ökat individuellt risktagande för de personer systemet ska ge skydd. För dem som hamnar för lågt träder en annan budget in och för dem som hamnar ovanför taket (avgifter till inkomstpensionen betalas på inkomster upp till 7,5 basbelopp) blir det i stället privat och kollektivt avtalade lösningar som präglar definitionen av en nivå.

Sensmoralen i detta är att det som garanteras över tid är ett pensionssystem, inte en pensionsnivå, vilket leder till att var och en som inte sedan tidigare vet att de hamnar under gränsen för garantipension, eller hamnar över gränsen för systemets räckvidd, rimligen inte kan antas ha en uppfattning om att få en "adekvat pension". Det krassa pensionslöftet utgörs av lägstapensionen, det vill säga garantipensionen. ${ }^{13}$ I övrigt garanteras alltså existensen av ett pensionssystem.

Pensionssystemets reformering har inneburit en stor förändring för människor. Det är ett faktum som lyfts fram av dåvarande statsministern Göran Persson år 2005 med orden: ”Jag är säker på att det vi gjort inte

I3. Vilket inte är fullt korrekt eftersom även garantipensionen har intjänanderegler i form av bland annat bosättningskrav, men dessa kompenseras i vissa fall genom regler om äldreförsörjningsstöd. 
kommer att vara populärt om 20 år, när de som går i pension ser vad vi gjort” (Expressen.se/TT 2005), och av förre socialförsäkringsministern Ulf Kristersson, som sex år senare uttryckte sig kritiskt om systemet med orden att en stor del av de försäkrade har "orimligt svårt att få en samlad bild av sin framtida pension" (Kristersson 20II).

Redan här skulle vi kunna säga att tes I är förkastad eftersom den är logiskt svår att uppnå. Men upplevelser är inte nödvändigtvis en fråga om logik i den mening som diskussionen ovan synliggör. Snarare är det så att människor kan förvänta sig en pension från systemet, det är bara svårt att avgöra hur mycket det blir om man befinner sig i det snitt som utgörs av inkomstpensionen. Begreppet "adekvat” fångar en avlägsen idé om vad som på ett övergripande plan kan ses som en acceptabel pensionsnivå (se Hvinden \& Schøyen 2013). När man talar med enskilda medborgare är denna relativa jämförelse något de kan greppa. Beroende på bland annat vilken ålder man befinner sig i grundar sig jämförelsen på olika saker. Det kan vara det tidigare pensionssystemet, det kan vara den information eller reklam man fătt sig tillsänd, och i de fall planer finns i hur dessa måste ändras eller kan upprätthållas. Dessutom påverkas upplevelsen av adekvat nivå rimligen av vad den ska räcka till. $\mathrm{Om}$ hushållsekonomin parallellt belastas med kostnader som följd av ändrade politiska ambitioner, till exempel minskad subvention av boende, läkemedel, sjukvård, tandvård, eller av press nedåt på lönenivåerna, med mera, så försvåras enskildas bedömning av vad som kan ses som adekvat. Pensionärer får inte del av de senaste årens jobbskatteavdrag och således är idén om pension som uppskjuten lön undergrävd här. ${ }^{14}$ Att riskerna förskjutits från kollektiv till enskild på många plan står dock klart.

\section{Erno, en vit svan}

En person som först blev arg och bestört över reformeringen är 50-årige Erno. Han var kritisk emot riskförskjutningen som skett genom att det kollektiva ansvaret försvagats och det individuella ansvaret förstärkts, men efter att ha satt sig in i informationen bedarrade indignationen och han ansåg sig nu kunna hålla kvar vid sina tidigare pensioneringsplaner:

14. Se Harrysson 2000 för en diskussion om oantastbarheten för pensioner. Se även Lindholm 2013 för argument kring denna speciella pensionärsbeskattning. 
Ja, jag blev förbannad. Det var ett jävla sätt. [...] De tog bara dän det. [...] Jag har hela tiden sagt till mig själv innan reformen att jag ska gå vid 6o, kanske trappa ner till halvtid och lyfta pensionsförsäkringen och så jobba halvtid. Jag tror ... om man går tillbaka till reformen. Alla snackar ju om att man förlorade massa pengar ... Men när jag får mitt rosa häfte ... plus de andra försäkringarna man har, [...] ekonomiskt kommer jag inte lida. Så planerna är fortfarande att kunna gå vid 60 .

\section{Bruno, en svart svan som grainats över tid}

Bruno intervjuades när han var runt 50 . Han levde ensam och arbetade heltid som tjänsteman. Han hade tidigare varit egenföretagare och pensionssparade då. Han fann pensionsförberedelser ointressant. Vid intervjun hade han inget sparande vid sidan om det allmänna och han kunde inte få ihop 15 ooo kronor på två veckor om det krävdes. Han upplevde det nya pensionssystemet som otryggt då det inte gav honom några garantier för hans framtida pensionsnivå. Han litade inte på att systemet skulle finnas kvar i sin nuvarande form i framtiden och räknade med att få ungefär 30 procent av sin inkomst i pension. Med bristande tillit till systemet, samt att han inte ansåg sig ha ekonomiskt utrymme att spara, fattade han beslutet att pensionsspara genom att amortera på huslånen så mycket som möjligt. Huset blev hans buffert. Inledningsvis gjorde han inga val i premiepensionen, men när han upptäckte att det gått minus aktiverade han sig och utvecklingen har sen dess gått lite bättre.

BRUNO: Jag tänker att man inte ska räkna med att det här systemet som finns nu finns då, utan jag tror att man ska försöka ha ... i form av att ha hus eller så ... att man kan klara sig själv. De här pengarna som finns på mitt konto ... när det gäller pension ... på de här olika ... Det är inte alls säkert att det finns kvar då ... Det är ju så hysteriskt många människor som går i pension nu ... [...] de slukar ju enormt mycket [...] alltså nu och tio femton år framåt. [...] Om man tänker rent realistiskt så kommer det att bli svårt att få det att gå ... att fungera ... tanken är god, men ... det kan nog bli problem. Man får nog tänka realistiskt och inte bara förlita sig på det här systemet. För annars kan man nog bli väldigt besviken när man går i pension ...

ERIKA: Hur mycket tror du att du kommer att få i pension?

BRUNO: Inte en aning. 


\section{Lowe, en svart svan}

Lowe, knappt 50 år, levde ensam och arbetade heltid $\mathrm{i}$ ett vårdyrke. Han hade inget pensionssparande, men ett sparande på I ooo kronor per månad (med buffert på 30 ooo kronor). Han stöttade sin mor ekonomiskt. Han trodde att hans framtida pensionsinkomst skulle hamna på cirka en tredjedel av hans inkomst vid intervjutillfället. Han kände då inte till att ett nytt pensionssystem införts. Han tog inte del av det orange kuvertet så noga, och inte heller informationen han fick hemskickad om tjänstepensionen.

ERIKA: Hur mycket tror du att du kommer att ha i pension? [Tystnad] Du kan säga andelsmässigt om det är lättare ...

LOWE: Om 20 år!?

ERIKA: Ja ... om vi säger att du har ... vi bara tar ett belopp för att utgå ifrån ... 20000 när du går i pension, hur stor andel av det tror du att du kommer att ha i pension? [...]

LOWE: Av detta? Knappt [tystnad] en tredjedel ...

ERIKA: En tredjedel ... 33 procent av ... [Erika och Lowe räknar] 7 ooo nånting tänker du?

LOWE: Ja ... men det har väl en vanlig pensionär ... man har väl en 5000-6 000 tror jag. Nåt sånt.

ERIKA: Hur väl känner du till reglerna kring pensionssystemet?

LOWE: Inte så bra måste jag säga [tystnad] alltså jag tänker inte så ofta på pengar över huvud taget. Jag är ... jag vet inte ... [småskratt]

ERIKA: Du vet att det är ett nytt pensionssystem i och med att du får det här orange kuvertet ... Känner du igen det?

LOWE: Nej [småskratt].

ERIKA: Nej ... innan så var det ju till exempel det här med ATP-poäng ...

LOWE: Poäng ja! Ja det vet jag att det fanns och inte finns längre, nu när du säger det, så det vet jag ...

ERIKA: Och innan så var det ju de Is bästa av $30^{15}$ som man har jobbat som var pensionsgrundande och nu är det hela livs... inkomsten ...

LOWE: Hela linjen ja ja ja ... [...] Nej det har jag inte alls ...

ERIKA: Hm ... och i din ... tjänstepension ... där är det ju också en del som kan läggas i fonder ... känner du igen det ...?

LOWE: Tjänstepension ...? [...] Nej ... jag är inte insatt i det heller ...

ERIKA: KPA ... känner du igen det?

15. I det gamla ATP-systemet innebar den så kallade 15/30-regeln att det räckte med 30 intjänandeår för att få full pension och att de $\mathrm{I} 5$ bästa inkomståren avgjorde hur hög pensionen blev. 
LOWE: Va?

ERIKA: KPA tror jag det kan vara om det är kommunalt ...

LOWE: Nä. Jag vet inte.

ERIKA: Så det är inget du känner igen att du gjorde nåt val där, utan det var de här ... den här premiepensionsdelen ${ }^{16}$ som du ... Hur gjorde du det? [...]

LOWE: $\mathrm{Hm}$... när var det ... det var en $4-5$ år sen? [...] Ja då satt jag och gick igenom ... jag vet att min far han hjälpte mig, han var ju mer duktig med det. Han fick inte själv nåt, i och med att han var väl 67 år då ... så frågade jag vad jag skulle ta. ”Ja inte vet jag!" sa han, ”Ta vad du vill, men ta några stycken”, och det gjorde jag ju också så jag tog en på 50 procent och två på 25 procent var ... [...] Ja, sprida lite ... ja ta nu några ryska och sånt tyckte han först. Men det har ju inte gått så bra med dem sen väl?

\section{Lisa, en desillusionerad svart svan som väcktes ur sin dvala}

Lisa, drygt 45 år, var frånskild och bodde vid intervjun med sina två tonårsbarn. Hennes skilsmässa hade varit besvärlig och hon hamnade i en svår sits. Hon tvingades lära sig "allt om ekonomi", eftersom hon tidigare hade förlitat sig på sin man. Det fanns inget ekonomiskt utrymme för vare sig pensionssparande eller kortsiktigt sparande. När hon levde som gift sparade hon både till sig själv och till barnen. Hon började pensionsspara 300 kronor per månad vid 32 års ålder och med siktet på att kunna sluta arbeta innan 65 . Nu, när hon levde ensam hade hennes förutsättningar vänts på ända och hon hade beslutat att jobba så länge som möjligt, både av ekonomiska och sociala skäl. Hon hade vid intervjun ingen kunskap om pensionssystemen.

När man hamnar i en sån här situation som man hamnat i när man skiljer sig så blir man nog mer ... man har ju förlitat sig på mannen - att han har skött allting ... Men nu gjorde han ju inte det i vårt äktenskap ... så det gick ju rent åt ... Så jag har ju fått mig en riktig så ... [...] och lärt mig oerhört mycket under det här året hur allting ... Man får ju sätta sig in i hur försäkringar och ... checka av ... och vad gäller det här och behöver jag ha det här eller ska jag ha något annat ... eller ... man har ju blivit rätt mycket klokare när man själv har fått ta del ... av sakerna ... Man bara förlitar sig ... Ja man förlitar sig på att männen sköter det och att det ... och visst. Jag litade ju på honom och sen att han fick problem och så, det har ju inte han haft hela vårt äktenskap. Så det ska jag ju inte säga, men jag har ju inte satt mig in i mycket sånt ... Och man är väl lite sån som tjej

I6. Lowe talade länge om premiepensionssparandet som sitt "privata sparande" under intervjun. 
att "det begriper jag inte ändå”. Och det är ju inte så! [...] Så det finns för- och nackdelar med mycket här i livet.

När hon startade sitt pensionssparande gjorde försäkringstjänstemannen en kalkyl över hur mycket hon skulle fà. Denna kalkyl har visat sig allt för optimistisk, och hennes förtroende för fondsparande blev av det ordentligt naggat i kanten. Hon blev av den erfarenheten försiktig med hur hon placerar sina eventuella sparpengar, men samtidigt mer intresserad och mer mottaglig för information i bland annat massmedierna än hon var tidigare. Hon pekade på att mer "riktad" information, exempelvis till kvinnor i hennes situation, vore bra. Några månader efter intervjun hörde Lisa av sig och tackade för att ha blivit upplyst om vikten av att engagera sig, vilket leder oss in på nästa tes.

\section{Sammanfattning tes $I$}

Förväntningarna på att ha en framtida säkrad pension varierar. Uppfattningen om hur stor den framtida pensionsinkomsten kan tänkas bli visade sig svår att besvara: drygt hälften kunde ge ett svar. Variationen var stor, allt från 30 procent av dagens inkomst till över Ioo procent. Medianvärdet hos dem som svarade låg på cirka 65 procent. Utöver denna osäkerhet är också kritiken gentemot individualiseringen återkommande då den egna kunskapen om systemets konstruktion upplevdes som bristfällig. Att pensionssystemet, och därigenom den framtida pensionsinkomsten, kan upplevas som svårt att begripa sig på för gemene man är inget unikum för det nuvarande systemet. Även det föregående systemet var komplicerat och därtill skedde kontinuerliga förändringar, vilka ledde till att pensionssystemet som helhet blev så gott som omöjligt att fånga (Palme 200I). Vad innebär då denna osäkerhet för människor?

\section{Tes 2}

I det reformerade pensionssystemet upplever de försäkrade sig förstå hur det skydd de garanteras av staten påverkar dem.

Ett centralt argument bakom det reformerade pensionssystemet var att öka den enskildes intresse och engagemang i sitt pensionssparande, för 
det handlar numera om ett mer uttalat personligt sparande livet igenom. Detta ska ske via två huvudspår: information och val. Det första spåret speglas av några olika insatser där det första handlar om det orange kuvertet som årligen skickas ut till alla försäkrade. I detta ges information dels om förväntad pension, dels om eventuell pension vid några olika scenarier där främst vald pensionsålder och ekonomisk tillväxt lyfts fram. Ett par olika webbplatser har dessutom utvecklats, utöver pensionsmyndighetens egen, vilka kan ge en översikt där även andra typer av pensioner än den allmänna presenteras. En central plats intar www.minpension.se.

Det andra spåret rör val och handlar om att den som själv kan påverka hur en del av pensionsmedlen placeras, men också ta ansvar för utfallet, engagerar sig mer. Att göra informerade val kräver förmåga att tolka tillgänglig information samt tid att göra det. Finansiell kunskap krävs alltså. Kring detta senare spår har en stor marknad växt fram med mängder av fondalternativ och även företag som erbjuder sig att sköta dina placeringar. Förvaltningsföretagen som växte fram använde tekniker för att flytta många fonder ofta och i klump i premiepensionssystemet, vilket lett till att denna typ av "automatisk omflyttning" sedan december 20 I förbjudits. Vi återkommer till detta andra spår i testen av tes $3 \mathrm{~b}$, och fortsätter här med informationsspåret.

Vilka anser att pensionsinformationen ger dem en känsla av att förstå systemet? Om vi uppmärksammar hur de försäkrade i Danmark ser på informationen de får om sin framtida pensionsinkomst så visar det sig att överskattning är vanligt, skriver Anna Amilon (2008). Hon fann dessutom ett bekymmersamt mönster $\mathrm{i}$ att personer som spår att de kommer få en låg pension oftare anser att den information de fått är tillräcklig, medan de försäkrade som har höga alternativt korrekta förväntningar på sin framtida pensionsinkomst oftare är negativare till pensionsinformationens tillräcklighet. Pensionssystemets utveckling och förändring, likt samhällsekonomin i stort, har lett till att vi som medborgare, med eller utan tillräcklig finansiell kunskap, i allt fler situationer förutsätts hantera risker och ta svåra ekonomiska beslut (Almenberg 20II; ISF 20I2). Det är en självklarhet att detta skapar olika ekonomiska förutsättningar och möjligheter för olika människor. Anna Amilons dilemma är intressant. 
Ju större du anser att ditt risktagande är, det vill säga ju större fallet från nuvarande inkomst till pensionsinkomst kan bli, desto mer bekymrade är vi över tillgången på information som gör att vi kan greppa situationen. Överfört till det svenska systemet blir detta den grupp vars allmänna pension i huvudsak hamnar inom gränserna för inkomstpensionen. Låginkomsttagaren faller tillbaka på att en garantipension är att förvänta, höginkomsttagaren på förmånsbestämda avtalspensioner och privata försäkringar, medan medelinkomsttagaren agerar på en arena där de endast kan påverka marginellt, men ändå förväntas agera informerat.

Vid vår genomgång av det omfattande empiriska material som ingår i vår studie har vi sorterat ut de som anser sig förstå pensionspyramidens samtliga tre delar av allmän, tjänstebaserad och privat pension. Sjuttioåtta personer intervjuades. Vår djupdykning i intervjumaterialet visar att den upplevda kunskapen är begränsad. Vi fann fyra personer som såg sig som "kunniga", varav tre uttryckte att de hade bra förståelse om pensionssystemet som helhet. De är tjänstemän och gifta och ingen planerar för att senarelägga sin pensionering. Två är födda 1939 och tillhör därför i huvudsak det tidigare systemet. Den tredje personen, som återkommer som en vit svan nedan under tes 3a, är Agnes, född I954 och 53 år vid intervjutillfället.

\section{Michael, en systemkritisk vit svan}

En annan vit svan var Michael, som var drygt 40 år och levde tillsammans med fru och barn. Varken han eller hans fru hade något pensionssparande och han motsatte sig pensionssparande då han inte ville låsa upp sina pengar. Han ville ha sitt kapital tillgängligt om behov skulle uppstå. Hans pensionsplan var att vid pensioneringen ha köpt de kapitalvaror han behöver och betalat av sina skulder. Han hade lite planer på att starta en kapitalförsäkring eller ett långsiktigt banksparande. Han räknade med att hans pension kommer att vara hälften av den lön han hade vid intervjutillfället. En av grundbultarna för att kunna uppleva att man har kunskap om pensionssystemet är att man skaffar sig information eller den hjälp man anser sig behöva. Detta gjorde Michael på egen hand och genom experter: 
Ja ... Jag har pratat med en kille jag känner, vi badar bastu ihop, och han jobbar nere på banken ... och då gick vi igenom. Ja just de olika uppläggen man brukar köra på ju [...] Nu när ... de där orange kuverten kommer i januari så skulle vi träffas på banken i hans tjänst och gå igenom både min och min frus för att se. För då hade han koll även vad man fick från facket och ... vad är det ...? Det är väl tre bitar tror jag det är, dels ... [tystnad] en liten bit man placerar själv: premiepensionen. Sen är det den, är det den där från arbetsgivaren och sen så från facket.

\section{Lotta, en kunnig svan i gråton}

Lotta var drygt 50 år och pensionssparade $\mathrm{I} 200$ kronor i månaden när vi träffade henne. Hon ville jobba 75 procent från 60 års ålder, om ekonomin tillät. Pensionssparandet började med 200 kronor i månaden när hon var runt 30 som hon ökade efter separationen från sin man. Hotet från att ha sett kollegor som fått sänka standarden som pensionärer hade gjort att hon inte ville hamna där själv. Hon handlade med aktier, något som hon lärt sig med hjälp av sin far. Pensionsinkomsten förväntades att bli bättre än vad hennes inkomst var då om hon gick i pension vid 65: 25000 mot 22600 . Om hon i stället gick vid 63 hade hon räknat ut att det skulle gå på ett ut.

Hon hade lärt sig i jobbet och av klienter att man måste ta hand om sin ekonomi, och då i synnerhet som kvinna. Det orange kuvertet ansåg hon som knepigt att läsa - ett siande om framtiden. Samma sak gällde informationen kring tjänstepensionen. Lotta visste att hon hörde till det nya pensionssystemet, men förstod inte riktigt vad det innebar. Hon hade ett stort intresse för ekonomi, men var kritisk till informationen hon fått hemskickad om såväl den allmänna som tjänstepensionen:

LOTTA: Jag har alltid [...] pysslat med fonder och aktier aktivt ... sen jag var i 25-årsåldern och har barn som håller på precis likadant. Så där att se om sitt bo. [...] Och sett att det går att göra pengar. På aktier till exempel. Och om man är intresserad av att hänga med så är det inte så himla svårt nej ...

ERIKA: När man är aktiv säger du ... hur menar du?

LOTTA: Det är många dagar i veckan jag kollar. Och kollar tidningen. Jag kollar hur det går. Ja det är spännande. [...] Jag tycker det är knepigt att läsa ut det [den allmänna pensionsinformationen]. Jag tycker det är det och det är ju liksom nu. Just i dag när jag öppnar kuvertet. Men för mig säger det inte särskilt mycket; hur ser det ut den dagen jag går i pension? [...] Jag är inte särskilt intresserad av det. Jag läser det och sparar det. 


\section{Peter, en svart svan}

Peter, 42 år gammal, hade inget pensionssparande alls. Frun pensionssparade. Han levde för stunden och barnen kostade just då. Med vännerna pratade han sport. Frun hade "tjatat", men han hade aldrig startat ett sparande, men kunde tänka sig det den dag då barnen flyttar hemifrån. Det orange kuvertet kunde han inte ens engagera sig i när pensionsfrågorna var så pass avlägsna. Han tyckte det var svårt med alla de ständiga valsituationer vardagslivet innefattas av.

Nej. Vet du om du tar en veckas period ... Hur mycket information får du hemskickat? Hur mycket ringer inte telefonen om kvällarna och de ska sälja ... du blir ju matad hela jävla tiden ... [ERIKA: Mm och det är du som ska ta beslutet ...] Ja och det är ju inte bara detta, det kan ... Man ska byta telefonbolag, man ska byta elbolag, man ska byta försäkringsbolag, du ska göra ditten och göra datten va? Och så mitt i allt detta ska man ta hand om allt det vanliga. Du vet hur man har det. Man har det ju stressigt i dag ju. Så man har inte ork att engagera sig.

\section{Anders, en medveten svart svan}

Anders, 55 år, reagerade mycket starkt när han första gången fick höra att var och en skulle spekulera med sina pensionspengar i det nya pensionssystemet:

Det är ju tokigt, för vi har ju inte alla den kunskapen och vi är ju inte alla lika bra på det. Jag kände att det blev ... det blev ... jag kände att jag tillhörde en grupp som blev utsåld på något sätt: "Nu får ni ta hand om er själva, och så får ni ... det är ditt ansvar nu", och jag har aldrig sett det så egentligen, utan jag har sett det som att det där med pensionen det är ett statligt ansvar. Det fixar sig den vägen. $\mathrm{Nu}$ är det ju inte hela pensionen ändå men [...] nä det var mer allergin mot att alla ska ut på aktiemarknaden. Alltså det var ju inte så bra ... men det var kanske en logisk följd av den här aktiemedvetenheten på något sätt som ändå berör en rätt begränsad del av befolkningen. Föreställer jag mig. Jag vet ju inte, men det tror jag.

Förväntningarna inför pensioneringen uppgav han var "skräckblandade" i och med att det förväntade inkomstbortfallet riskerade rendera i en ekonomiskt mager tillvaro. Han borde ta ett större ansvar och exempelvis starta ett privat pensionssparande påpekade han. Det var till och med så pass ruggiga frågor att han ogärna tog upp dem till diskussion med 
frun. Han hade ingen kunskap om hur pensionssystemet fungerar och hur de olika delarna förhåller sig till varandra. Det är frågor som han inte gillade, men "min strategi är ju helt förkastlig! Den är ju mer struts ... ner med huvudet i sanden va? Jag vill ju inte öppna det där orange kuvertet eller så. Jag vill inte ... man bara hajar till. 'Det här är ju inte sant. Det måste vara något fel, det kommer säkert en rättelse nästa vecka.' [Skratt] Men det gör det ju inte va!?”

När vi diskuterade vad han ansåg är en rimlig pensionsålder sa han:

Jag har alltid haft en tilltro till någon sorts evig tillväxt - att jag skulle kunna pensionera mig vid 60 och så vidare, och så vidare - och att allt skulle bli bättre och bättre ... Det har jag slutat att tro [...] Det kommer inte att bli så va? Jag kommer inte att kunna pensionera mig vid 60 års ålder. Det kommer inte att bli bättre och bättre ... utan det här med pensionen det liksom ... det vill jag helst inte tänka på egentligen ... Jag ser det liksom inte så ... Jag ser inte så ljust på det va? Det finns där och det kommer säkert att ordna sig på nåt sätt, men ... Tja [...] då jobbar jag till 65 tänker jag ... Men siffran 67 dyker också upp av och till? Jag tänker att ska det bli där i stället va?

\section{Sammanfattning tes 2}

Även i tes 2 finns såväl vita som svarta svanar. Vi har de informerade intervjupersonerna som uttrycker ett målrationellt tankesätt i relation till sina pensionsföreberedelser. Men bara för att man är en vit svan, så innebär inte det per automatik att man är positivt inställd till systemet som helhet. Inte heller innebär medvetenhet automatiskt förståelse. Våra exempel bjuder till exempel på vita svanar som inte litar på pensionssystemen, utan i stället väljer att gå sin egen väg. Individualiseringen av systemet tenderar att leda till att vi delar upp våra farhågor kring pensionssystemets framtida utfall i ett "jag och de andra". Vi kanske är någorlunda trygga för egen del, samtidigt som vi ser stora risker för att personer med sämre förutsättningar kommer att få det bekymmersamt.

\section{Tes $3 \mathrm{a}$}

I det reformerade pensionssystemet upplever de försäkrade sig ha större inflytande över sin framtida pensionsinkomst. 
Att ha inflytande åtföljs av att kunna påverka det ansvar som belastar mig som enskild, det vill säga påverka upplevelsen av frihet. Det ska inte missförstås som rätten att göra val även om val kan vara en del av ett sådant inflytande, utan ses i bemärkelsen av hur möjligheter och begränsningar upplevs ge mig förmågan att faktiskt göra dem (se t.ex. Sen 1992 eller 200I). När ansvaret upplevs tyngre än friheten som frigörs av reformeringen överväger alltså begränsningarna i en persons liv, och upplevs därmed som minskat inflytande. Man kan tänka sig att det är bland de personer med begränsade möjligheter att lösa en adekvat ålderdomsförsörjning på annat sätt än i ett offentligt system som vi finner personer som står inför detta dilemma, men så såg det inte riktigt ut bland dem vi träffade.

Livsinkomstprincipen för med sig att olika karriärer genom livet påverkar den framtida pensionen. Unga personer är förhållandevis mer positivt inställda till att genom egna val öka sitt inflytande i relation till sin framtida pensionsinkomst. De upplever att de har livet på sig. Att ha tillräcklig kunskap om pensionssystemet, eller egentligen fondplaceringar, krävs för att uppleva sig ha ett stort inflytande, anser exempelvis Lotta som vi mötte ovan. De som känner att de har inflytande över sin framtida pensionsinkomst är en liten elit av "reflexiva planerare för framtiden" (Denton m.fl. 2004). Eliten är de som har ekonomisk möjlighet och social förmåga att själva, eller med hjälp av experter, göra val och placeringar.

Det finns olika anledningar till varför känslan av eller medvetenheten om ett större inflytande över sin framtida pension skiljer sig åt. De yngre har (i större utsträckning än övriga åldersgrupper) tagit till sig information och förstått det egna ansvaret och hur livsinkomstprincipen får stor betydelse för deras framtida pension, men variationerna ifråga om pensionsslag är stora. En annan anledning visar sig när man drabbas av ohälsa och inser att man måste anpassa sig till situationen. Då handlar det inte om antaganden eller förmågan att ta till sig information, utan om vardagsrealiteter. Berit, 55 år, och Åke, 50, är exempel på personer som på grund av hälsoskäl kommit till klarhet med hur/om de kunde/ ville påverka sin framtida pensionsinkomst. Åke genom att välja att inte ha en långsiktig planering och i stället leva mer i nuet, medan Berit valde 
att genom arbete, sparande och avbetalningar på lån möjliggöra en tidigarelagd pensionering.

\title{
Agnes, en vit svan som "köper läget"
}

Agnes var 53 år och en person som ansåg sig ha någorlunda kunskap om hur systemet fungerar, även om hon vägrade att aktivera sig när det gäller sin pension. Hon var genuint besviken på hur systemet har reformerats och hur olika det slår mot olika grupper:

\begin{abstract}
Alltså på nåt sätt känns det som om man lämnar, och det är väl där systemskiftet var - att lämna var och en till sitt öde och ingen kan säga att man har placerat fel utan du har själv gjort det. Jag har kunskap och jag kan välja att göra det men jag väljer bort det för jag skiter i det, men de som inte har det ... och där tänker jag många svagbegåvade som inte har det så lätt för sig. Vem ska sköta det till dem? Vem bevakar att deras pengar förvaltas rätt?
\end{abstract}

\section{Eli, en svart samhällsmedveten svan}

Eli var knappt 50 år gammal vid intervjutillfället. Han flydde i 25-årsåldern till Sverige från forna Jugoslavien. Han hade en bra utbildning i bagaget och kunde av den anledningen relativt snabbt hitta sin väg in på den svenska arbetsmarknaden. Han arbetar i dag i ett administrativt yrke. Eli är kritisk till hur delar av vårt socialförsäkringssystem, till exempel pensionssystemet, fungerar. Han påpekar att han själv, så klart, är påverkad av sina livserfarenheter och de samhällskriser och samhällsomvälvningar som skedde i forna Jugoslavien och trycker därför på vikten av att politiker måste ha fokus på samhällsnyttan och ha med i beräkningen hur många och vilka samhällsgrupper som exkluderas i eller av en socialförsäkring. Han är mycket medveten om att han kommer att få en betydligt sämre ekonomisk situation dagen då han går i pension.

Jag ska inte säga att jag känner till helheten, men jag är någorlunda insatt i det och jag vet ungefär hur mycket jag kommer att få och hur jag vill ha det när jag går i pension. Och jag är fullt medveten om att så som jag lever i dag kommer jag inte att kunna göra när jag går i pension. Så mycket kan jag säga. För ... dels så är pensionen väldigt liten i förhållande till inkomsten och dels så ... är den byggd på ett sätt som faktiskt gynnar höginkomsttagare. [...] Alltså dagens löner ... Jag har en sambo som jobbar på [arbetsplats] och hon säger: "Min lön går bara runt. Jag får min lön den 25:e, sen går den vidare till sista dagen i måna- 
den.” Så långt räcker hennes lön. Så långt räcker det. Och då kan man undra, vad ger det här på lång sikt? Vad ger det här i pensionspoäng? Klyftan mellan höginkomsttagare och låginkomsttagare har ökat. Och sen pratar vi om ett jämlikt och jämställt pensionssystem. Jag tycker inte att det är det faktiskt. [...] Nej, det tycker jag inte, om vi tänker pengar så är systemet stabilt men om vi tänker samhällseffekter så är det instabilt.

\section{Sofie, en riktigt grå svan}

Sofie var 35 år gammal och en av dem som ställde sig positiv till att som försäkrad ha ett större inflytande över sin framtida pensionsinkomst. Däremot var steget långt från att vara positivt inställd till att ägna den någon direkt tanke:

Jag vet att för något år sen så pratade dom ju mycket om att höja pensionsåldern. Att man skulle vara mer flexibel och ... sen har det ju stått en del om att pensionsåldern kommer att höjas och att vi kommer att få jobba mycket längre och såna saker och det läser man ju. Men jag funderar inte så mycket på det över huvud taget faktiskt. Alltså jag tycker ju på ett sätt att det är jättepositivt att man kan välja när man vill ... för vissa vill ju gärna jobba längre och för dom är ju det jättepositivt ... Så på det viset kan jag ju tänka på det. Men jag tänker inte på det som för mig själv, nä det gör jag inte.

\section{Vera, en rik svan}

Vera, 6o år, var änka och hade pensionssparat 300 kronor i månaden i tio år när pratet om att pengarna inte skulle räcka till pensionen var som mest högljutt. Allt det som hennes man sparat tillföll henne när han gick bort. Hon såg sig som rik. Spekulationerna på fondmarknaden ställde hon sig kritisk till. Vera hade inget intresse av privata investeringar eller premiepensionen utan tog hjälp av experter, vilket var möjligt eftersom hon hade mycket pengar. Hon gillade inte att bli tvingat aktiv.

Jag har ju synpunkter på det här pensionssystemet. Nä, alltså ... med de värderingar jag har i botten så är jag inte så förtjust [...] Det är väl det här att man då ska ... spekulera. För här har du ju skillnaderna. För om du tittar på mina föräldrars generation. Alltså det här var ju revolutionerande när man införde det gamla pensionssystemet att ... Tjänstepensionen ... ha den här tryggheten på äldre dar och man behövde inte oroa sig som deras föräldrar hade behövt göra va? Vad man ska leva på under ålderdomen och om man hamnar på fattighus och så det var ju den stora grejen då. Och då var det ju inbyggt den här trygg- 
heten. På nåt sätt så garanterade ju staten ens trygghet på ålderdomen. Men det gör man inte längre. Nu ska du själv se till att förränta de här dina skattepengar och då är du ju beroende av marknaden, alltså indirekt så styr marknaden din trygghet där på ålderdomen.

Att tillskrivas ökade valmöjligheter i till exempel fondval, eller andra välfärdsval innebär inte att man automatiskt får ökat inflytande över framtiden. Däremot verkar det skapa både förvirring och osäkerhet. ${ }^{17}$

\section{Lena, en vingbruten svart svan}

Lena arbetade deltid inom ett tjänstemannayrke och var 33 år. Det var hennes andra "riktiga" arbete. Hon var inte intresserad av pensionsförberedelse. 1993 hade hon blivit uppringd av en försäkringstjänsteman och inbjuden för att diskutera privat pensionsförsäkring. Mötet slutade med att hon började pensionsspara 200 kronor per månad. Två år senare slutade hon med inbetalningarna på grund av sin dåliga ekonomi. Sparandet var fortfarande vilande:

Ja det var ju en snubbe som lyckades övertala mig. Jag tror han ringde ... och var jättetrevlig och sa "ja men om du är osäker så kom ner till vårt kontor så kan vi prata lite mer" och allting var så tjusigt och så där ... Jag vet inte vad man föll för egentligen ... för ... det lät trevligt det han sa liksom. Så jag tänkte att ja varför inte ... ja det var nog det med att man kunde dra av det på deklarationen. Ja det var det. Så det var nog av den anledningen. Nu har man kanske ändrat inställningen lite när det gäller det.

\section{Svanarna och skulden}

Pensionssystemet är precis som annan försäkring en kollektiv ordning, men i det allmänna och reformerade pensionssystemet är medlemskapet tvingat, det enskilda ansvaret för utfallet omfattande, och det individuella inflytandet begränsat. Som så ofta dyker skuldkänslor upp i människors tankar; att de hela tiden vet med sig att de borde, skulle eller förväntas göra mer än de gör för att kunna påverka sin framtida pension. System som framkallar skam- och skuldkänslor ${ }^{18}$ (upplevt stigma) blir

I7. Se Kahneman, Odean \& Barber 2005. I denna klassiska artikel exemplifieras pensionsval med hur en pilot kommer ut till passageraren och ber denne ta över spakarna. I8. För skam och stigma se t.ex. Dahlgren 20II och Dahlgren \& Starrin 2004. 
allt vanligare och är speciellt effektiva om skälet till känslan kan tillskrivas personen själv (ett slags "skuldbeläggande av offret").

Det finns en känsla av skuld bland de intervjuade i att de inte satt sig in i frågan så mycket som de borde. $\mathrm{Om}$ de hade varit intresserade, läst all information eller "gjort som de skulle", så hade de kanske fått verktyg för att kunna känna sig säkrare på pensionsområdet. Men för många såg det inte alls ut så. De var inte oinformerade. Deltidsanställda, lågavlönade (fattiga) och sjuka, som till exempel Kristin, drygt 55 år gammal, hade helt enkelt inte pengar att göra det som de trodde de måste göra för att få inflytande över sin framtida pensionsinkomst. Ann-Charlotte, också runt de 55, hade varken haft ork eller intresse och därför valt att inte aktivera sig eller ta till sig någon pensionsinformation. Valet är medvetet och hon visste att hon kanske egentligen borde aktiverat sig:

Jag orkade inte engagera mig. För att jag ... tänker väl att det ordnar sig kanske ... [skratt] [...] Jag var ute på min praktikplats då, så det var ju där jag hörde hur ... de ... alltså jagade upp sig för detta. Men ... nej jag vet inte om jag blundar för det eller ... Det är väl mest att jag inte är intresserad av sånt. Det är jag inte. Det borde jag kanske vara, men ...

Anders, vår medvetna svarta svan, lyfte fram sin analys av spekulation i systemet:

Och då tänkte jag att jaha nu fick det ett sånt genomslag till slut ändå va? [...] Men jag gjorde ... så klart, i och med att jag är struts i det fallet så är det klart att jag inte brydde mig ... men jag tänkte på det och jag kastade aldrig några papper, men dom har jag. Men dom lägger jag på en hylla och så ligger de där och [skratt] [...] och studsar i min ångest ... Nej jag bara lägger på nya papper när jag får dem året därpå! Så jag hade väl tänkt att jag skulle göra någonting då, men så gjorde jag inte det. Och i backspegeln kan jag väl säga att det var rätt logiskt när jag känner mig själv.

Han tog inte riktigt del av den information han fick från de olika delarna i pensionssystemet. Han öppnade och läste, men inte på något djupare sätt. Han menade att det hade med hans "korkade personlighet" att göra och syftade på att det smarta i det här läget hade varit att engagera sig, göra aktiva val och avsätta pengar till ett pensionssparande. Men samtidigt var motivationen för detta inte tillräckligt stark, då det inte finns 
några garantier att de pengar han avsatte $\mathrm{i}$ ett pensionssparande växte till sig.

Det handlar ju ändå om att göra det bästa av situationen. Att så klart det är ju bättre att agera själv och sen får man ju göra så gott man kan. Det är så klart att sen ... Om jag inte gör det och lyckas - då har jag ju bara haft bondtur liksom va? Att vara passiv ... då ... ja ... då är ju risken större att det blir sämre ...

En annan aspekt av att känna skuld, och kanske till och med otillräcklighetskänslor, uttrycktes av Nina, 55 år, när hon som förälder till vuxna barn uppgav sig sakna både kunskap och mod att råda sina barn i frågor om exempelvis fondplacering och pensionssparande. Inte minst då hon ansåg att den bristande kunskapen med stor sannolikhet skulle kunna innebära att ge sitt barn bristfälliga råd. När frågan om individens ökade ansvar ställdes så tystnade hon en stund, sedan suckade hon och sade:

Alltså det krävs ju att man är ... mer aktiv och att man är lite intresserad och jag tror att det känns stort för många. Så man liksom ... man bryr sig inte och framför allt ju yngre man är desto mera avlägset är det på något vis. Om man tänker på sina barn ... som om dottern ringer och frågar: "Vad ska jag göra med det här?! Hur ska jag välja?” Jag vet inte! Jag vill inte vara den som säger välj det eller välj det, utan jag vet att hon har valt att bara låta det vara och det har ju visat sig vara ett bra val. I stället för då när man blev uppmanad att sätta sig in i alla dessa femhundra olika och välja någonting va? Jag tror att det är mycket begärt att räkna med att man ska vara intresserad.

Nina får bilda en naturlig övergång till tes $3 b$.

\section{Tes $3 b$}

I det reformerade pensionssystemet upplever de försäkrade ett ökat intresse för att välja hur de ska placera sina sparmedel.

En viktig del i reformeringen av pensionssystemet var för vissa partier i uppgörelsen möjligheten för personer att själva placera och fondera sina uppsamlade pensionsmedel. Vi är alltså tillbaka till det andra spår som diskuterades i samband med tes 2. Argumentet bygger på ett beteendeantagande om att människor är bäst på att maximera sin egen nytta, 
varför det faller sig rimligt att så stor del som möjligt av det offentliga tvångssparandet lämnas åt den enskilde att själv förvalta. Argumentet ligger i linje med en idé om att möjligheter och begränsningar ska gå hand i hand. Det vill säga: flyttas ansvaret för utfallet från det allmänna till den enskilde så ska också inflytandet över medlen flyttas. Ett problem med argumentet är frågan om skälet till tvånget; att försäkra medborgarna om ålderdomsförsörjning. Människor i allmänhet har inget emot att bestämma över och ta ansvar för sina liv, men för finansiell placering krävs förmågan att förutse risker långt fram i tiden. Få klarar detta, inte ens ekonomiska experter som bygger sina framskrivningar på avancerade modeller utifrån data om historien. ${ }^{19}$ Tvångssparande som kollektiv försäkringsform används för att sprida riskerna så brett som möjligt i ett osäkert scenario för samhällsekonomins utveckling. ${ }^{20}$ För att återkoppla till den första tesen så är möjligheten att maximera nytta inte detsamma som adekvat pension. Antagandet om maximerad nytta på ett avgränsat område bygger dessutom på att det finns ett intresse och en förmåga isolerad från andra avgörande händelser i livet. Pensionsfrågan är ett ämne som dessvärre förefaller ointressant för många människor (Ring 20Io; Werner 20I2). Det blir då inte speciellt avlägset att anta, till skillnad från att se system i isolering, att människor ser en förutsägbar allmän pension på adekvat nivå som en möjliggörare för att engagera sig i annan mer produktiv verksamhet, till exempel att skaffa barn, utbilda sig, göra yrkeskarriär, och bygga ett hem. För den med större ambitioner och tillgångar att riskera finns den privata försäkringsmarknaden. Människor lever sina liv i vardagen och prioriterar utgifter som rör nuet - fotbollsavgifter till barnen, semesterresor eller badrumsrenoveringar. För låginkomstgrupper är denna nutidsorientering självklar med utgiftsprioriteringar som inte handlar om exempel som ovan utan om mat på bordet och inbetald hyra (se t.ex. Hjort 2004). Livsinkomstprincipens "varje

19. Demografisk statistik anses som en av de dataformer som ger möjligheter till rätt stabila framskrivningar (prognoser). Men detta är på aggregerad nivå, inte enskild. Livstidstabeller användes till exempel historiskt som grund för beräkning av risker i liv- och pensionsförsäkring. Se t.ex. Hacking 1990; även kommenterat i Harrysson 2000.

20. Se t.ex. Mannelqvist 2003, kapitel 4. Även ett äldre verk som Schmidt 1974 ger en introduktion till detta (i kapitel I). 
dags arbete räknas” står sig inte sällan slätt emot människors vardagliga prioriteringar, vilket Peter (född 1965) gav exempel på ovan.

\section{Benny, vår vitaste svan}

Fastighetsskötaren Benny var en av de unga, 36 år, som ställde sig positiv till möjligheten att göra val och påverka sin framtida pensionsinkomst. Han menade att ett sätt att påverka sitt inflytande är att aktivera sig i premiepensiondelen. Han var en av få som gjorde det. Han var fullständigt ointresserad av pensionen i allmänhet och tog inte del av det orange kuvertet, men när det gäller premiepensionen så uppgav han att han "bettar rätt friskt". Han vågade "leka” mer med den då ”det känns som om man kan spekulera med PPM-pengarna mer! Det är ju så långt in i framtiden så det ... det hinner man ta igen”. Han var mycket aktiv och såg varje vecka över sina placeringar för att se om det var läge att byta. Hans offensiva strategi hade burit frukt och under året innan intervjun så fördubblade han värdet av sin premiepension.

\section{Lotta, en kunnig svan i gråton - igen}

Lotta var aktiv i det privata sparandet:

Ja. Det är ju lite mer engagemang kring det ja. Jag följer med mycket och kör lite statistik själv hemma på datorn. Och ser vad som hänt och ser vad som har hänt på en månad och ett halvår och ett år och så. Jag jobbar ganska aktivt. [...] När jag jobbar med aktier så är det väl att jag tänker mig upp till den summan och sen chansar jag inte mer utan jag säljer då. Och sen sparar jag vinsten och investerar i den summan jag hade från början, ja det är det ju. Man märker ju hur det växer!

\section{Lillian, en svart svan}

Lillian pensionssparade 200 kronor i månaden sedan tre år tillbaka då hon var 47 år. Hon började när sonen flyttade hemifrån och pengar frigjordes. Hon fick ut 15500 kronor per månad i lön och ansåg sig välbetald. Hon såg huset som sin investering och den huvudsakliga bufferten inför framtiden, men upplevde sig ha blivit lurad genom reformeringen av pensionssystemet när 15/30-regeln slopades. "Kommer jag få någon pension över huvud taget?” Lillian förklarade hur hon såg på att pensionen blivit individens eget ansvar genom att jämföra med att köpa mjölk: 
När man fick det här orange kuvertet. Då tänkte jag så här ... alltså hur kan dom låta gemene man ta så stort ansvar för nånting som är så svårt ... [...] Information ska jag inte säga att inte det finns. Det gör det. Men att ta det till sig och att förstå ... Alltså jag tycker att det har varit svårt. Och så just det här att rätt som det är får du ett papper hem där det står att "Nu ska vi inte ha ... Vi rekommenderar dig att byta till någonting annat - den har inte gått så bra den här fonden”, och då tänker jag så här ... vaddå!? Varför gör ni så? [Skrattar] Vad elaka ni är! Där tycker jag att jag satsar mina småpotatisar där, och då tycker jag att de ska växa till sig. [...] Det hänger ju ändå på mig ju! Och då ska jag återigen göra ett val och jag tycker inte att det är lätt. [...] Det är ju som att gå in i affären och handla mjölk till någon som sagt "köp en liter mjölk till mig", så står man där och tittar ... vilken mjölk vill du ha!? Och så tar man den som man själv tycker om därför att man vet inte bättre! Nä! [Skrattar] Alltså man kan bli så ställd av alla de här valen. Och jag kan tycka alla val i sig. Inte bara att du ska välja till pensionen. Plötsligt ska du välja elbolag och telenätet ... och du ska tjäna pengar och du ska inte lägga så mycket pengar i onödan! Och det ska vara billigt och det ska ... Alltså det kan göra mig väldigt frustrerad.

\section{Sammanfattning tes $3 \mathrm{a}$ och $\mathrm{b}$}

Bland de yngre respondenterna var det oftare en något mer positiv syn på det egna ansvaret och de egna valen i systemet. Den här åsikten kan vägas emot de som är kritiska mot hur den tidigare kollektiva basen försvagats och bitvis försvunnit genom reformeringen. Särskilt stark var de kritiska kommentarer som kom från de (främst kvinnor) som tillhör de första generationerna som får hela sin pension ur det nya systemet. Kritiken och besvikelsen var tydlig, många berättade att de planerat sitt liv efter de tidigare reglerna (främst I5/30-regeln) och nu är reglerna ombytta, vilket har lett till en lägre framtida pension och kanske även ett (krav på) längre arbetsliv.

Det finns också en påtaglig skiljelinje mellan de som "kan" och de som "inte kan". Den kunnige har ofta ett intresse sedan tidigare eller har sökt sig hjälp och stöd från en expert, för att på så sätt kunna göra informerade val. Benny säger att han "bettar rätt friskt" med premiepensionen och att han vågar göra det, då det känns mer tillåtet att göra det med den delen av pensionen. Att vara aktiv innebär med andra ord att intresse och upplevt inflytande varierar mellan systemets olika delar. De som varken är intresserade eller upplever inflytande är i klar majoritet och de menar att det beror på okunskap och att systemet som helhet är svårt att förstå sig på. 


\section{Avslutande diskussion}

De fyra teser som vi testat i föregående avsnitt bär ett centralt och gemensamt drag, ett antagande om att människan är handlingskraftig och förmögen att bedöma och ta tillvara på de förutsättningar som ges. Vi har mött många handlingskraftiga personer, men få med av sig själva uppfattad förmåga att se in i framtiden och kunna hantera kortsiktigt beteende med långsiktiga konsekvenser på ett område omgärdat av så många osäkerheter som pensioner. I ett sådant perspektiv blir individualiseringen av riskerna i ett obligatoriskt försäkringssystem svår att greppa på annat sätt än att gemensamma åtaganden ideologiskt är "ute" till förmån för individuella lösningar. Ett problem är att inte alla har förmågan eller resurserna att ta sig an utmaningen, inte heller nödvändigtvis viljan att på egen hand ge sig i kast med den. ${ }^{21}$

Det är inte lätt att förkasta teoretiska antaganden där "pudelns kärna" är så pass välskyddad som behavioristiska antaganden om rationellt beteende (egentligen att handlingar ex post är rationella ex ante). Vi har i vår framställning visat att avstånden mellan de politiska intentionerna i en reform och medborgarnas upplevelser av dem, samt mellan uppbackande teori och upplevd praktik, är stora. Att som vi försöka illustrera mötet dem emellan är inte helt lätt. Den bild vi presenterat utifrån enskildas berättelser och illustrerad med hjälp av vår svanmetafor visar bland annat att administrativa systems sätt att knyta politisk intention till medborgarens praktik kan synas rimlig i en "de styrandes" logik, men för den enskilde medborgaren framstå som fullständigt obegriplig. ${ }^{22}$

En medborgerlig tillit till politiska system är basen för deras legitimitet och överlevnad. Stefan Svallfors har med hjälp av Välfärdsstatsundersökningen kunnat visa att människors tillit till delar av vårt välfärdssystem har försvagats. Pensionssystemet är ett av dem. Han har också visat att det finns tydliga klasskillnader i förtroendet, där tilliten hos männis-

2I. Se t.ex. Bourdieu 2005 för en mer långtgående och fördjupad diskussion kring mötet mellan struktur och aktör. Exemplet som Bourdieu använder rör bostadsmarknaden, eller mer precist enskilda hem, vilket i likhet med pensioner utgör en komplex och svårgripbar investering över lång tid.

22. Se t.ex. Bjerstedt 2009 om den dynamiska process som försiggår mellan definitionsmakt, fördelning och medborgarskap. 
kor på marginalen är svagast. "Att de grupper som är mest beroende av socialförsäkringen har det lägsta förtroendet för att den faktiskt fungerar kan på ett vis ses som ett politiskt misslyckande. Om en av välfärdspolitikens viktigaste uppgifter är att garantera marknadssvaga grupper en dräglig tillvaro är det naturligtvis ett problem om många av dem inte anser att den klarar denna uppgift” (Svallfors 20II, s. 39). På samma vis, men på en europeisk i stället för en nationell nivå, noterar förre finansministern Anders Borg i en debattartikel i Dagens Nyheter: "Förtroende bland hushåll och företag för hållbara offentliga finanser är en grundförutsättning för att budgetstimulanserna ska få effekt och bidra till att stabilisera den svaga konjunkturen” (Borg 20I3). Avgörande för ett välfärdssystems legitimitet och funktion är alltså att människor uppfattar att det gör det som det säger att det ska göra.

Det går att ifrågasätta om den administrativa apparaten mer ska framstå som något, än faktiskt vara det. Vi är inte de första som funderar över detta. Michel Foucault utvecklade begreppet "gouvernementalité" ("styrningskonst"), som på ett sätt kan sägas fånga denna frågeställning (Foucault 199I). Hur skapas styrning, hur operationaliseras den och hur upprätthålls den? En dimension av "styrningskonsten" består i att se hur ett fenomen, $i$ vårt fall pensionssystemet, betraktas och beskrivs av de styrande, det vill säga beskriva det som styrningens synlighetsfält. Vissa delar accentueras, medan andra försvagas. På vilket sätt synliggörs pensionssystemet och dess utfall av de styrande (Werner 20I2)? Några tydliga aspekter av systemet är att det är teknifierat, automatiserat och individualiserat, men också att det administreras av en byråkrati vars huvudsakliga uppgift är att utföra, inte förändra eller ifrågasätta. En av oss presenterade sin avhandling vid ett stort symposium anordnat av bland annat Pensionsmyndigheten våren 2013. Att som vi här ifrågasätta systemets sätt att möta människors behov baserat på narrativa data ifrågasattes då av myndighetens företrädare på basis av att de inte är generaliserbara till att gälla hela den försäkrade populationen (Werner 20I3). Det är korrekt om ambitionen är att finna mätbara storheter, men likväl har vi illustrerat en variation i bilden av systemets konsekvenser som påvisar existensen av bristande korrespondens mellan uttalade politiska reformintentioner och upplevda konsekvenser av dem. Det var inte så svårt att hitta svarta 
svanar, metaforiskt uttryckt, såväl bland dem med sitt på det torra som bland dem i en mer utsatt situation. För flera av de vita svanarna kan det dessutom sägas att deras fokus flyttats till ett finansiellt intresse snarare än pension som sådan.

Grundläggande behov som boende och hälsa, är områden som under senare tid i allt större utsträckning kommersialiserats likt mat för dagen. Avreglering och privatisering, ökande inslag av vinstmotiv och spekulation ger vid handen att ålderdomsförsörjning inte endast är en fråga om inkomst, utan en fråga om hur stor andel av inkomsten som måste läggas på dessa grundläggande behov. Att leva enbart på en garantipension innebär i dagens Sverige att du i princip riskerar att inte ha råd med bostad då de relativa bostadsutgifterna oberoende av boendeform växt under lång tid. ${ }^{23}$ Detta kan givetvis inte skyllas på pensionssystemet $\mathrm{i}$ isolering, garantipensionen är trots allt högre än vad folkpensionen tidigare var. Nej, det handlar om det komplexa sambandet mellan olika välfärdsordningar och hur dessa organiseras, styrs och presenteras. Ökad girighet, även bara i mindre grad på varje område, bildar samfällt en effekt som kan slå hårt mot alla, men speciellt mot grupper som redan lever nära sina ekonomiska marginaler. Ett pensionssystem med företrädare som slår sig för bröstet för dess utomordentlighet, gärna med referens till omvärldens avund, avstår helst från att diskutera hur systemets legitimitet ska stå pall bland till exempel de 25 procent ungdomar som inte kommer in på arbetsmarknaden. De 25 procent ungdomar som i debatten ibland framställs som att de begär för hög lön för att få ett jobb, trots att de inte diskuterar någon lönenivå utan endast hoppas på en anställning efter utbildning och jobbsökande. ${ }^{24}$ Ur deras perspektiv finns det faktiskt inget i detta pensionssystem att slå sig för bröstet om. Det är rentav ett hån mot medborgarna att göra det. Social arrogans kallas det (Helldén 1994).

23. Se Boverkets rapport Boendekostnader och boendeutgifter - Sverige och Europa (Boverket 2009). I rapporten framhålls bland annat att boendekostnaderna i relation till den disponibla inkomsten sjunkit under senare år till följd av att skatterna sänkts. Detta är ur pensionsperspektivet en sanning med modifikation då pensionärer inte får del av de skattesänkningar som förankras i så kallat jobbskatteavdrag. Rapporten visar däremot att boende som del av hushållens utgifter är högst i Europa, runt 27 procent.

24. Bland många möjliga, se t.ex. Ohlsson 2007. 


\section{Referenser}

Almenberg, Johan (20II) "Räknefärdighet och finansiell förmåga", i Ekonomisk Debatt, nr 5 , årgång 39, s. 17-32.

Amilon, Anna (2008) Danskernes forventninger til pension. Rapport från SFI - Det Nationale Forskningscenter for Velfærd.

URL: http://www.sfi.dk/resultater-4726.aspx?Action=I\&NewsId=29\&PID=9422 (2I augusti 20I4)

Bjerstedt, Daniel (2009) Tryggheten inför rätta. Om rätten till förtidspension enligt förvaltningsdomstolarna under tre decennier. Avhandling från Lunds universitet.

Borg, Anders (2013) "Bara tillväxt och utbildning kan rädda EU:s ekonomier", i Dagens Nyheter 29 maj 2013.

URL: http://www.dn.se/debatt/bara-tillvaxt-och-utbildning-kan-radda-eusekonomier/ (2I augusti 20I4)

Bourdieu, Pierre (2005) The social structures of the economy. Oxford: Polity Press.

Boverket (2009) Boendekostnader och boendeutgifter - Sverige och Europa. Rapport från Boverket.

URL: http://www.boverket.se/Global/Webbokhandel/Dokument/20Io/

Boendekostnader\%20och\%2oboendeutgifter\%20-\%20Sverige\%20och\%2oEuropa.pdf (2I augusti 20I4)

Chalmers, Alan F. (1999) What is this thing called science? 3 uppl. Buckingham: Open University Press.

Dahlgren, Lars (20II) För att bättre förstå. Folkhälsan speglad i emotionssociologi och grundad teori. Lund: Studentlitteratur.

Dahlgren, Lars \& Starrin, Bengt (2004) Emotioner, vardagsliv \& sambälle. En introduktion till emotionssociologi. Malmö: Liber.

Denton, Margaret A. m.fl. (2004) "Reflexive planning for later life", i Canadian Journal on Aging, volym 23, supplement, s. 71-82.

Dor: http://dx.doi.org/I0.1353/cja.2005.0031

Expressen.se/TT (2005) "Persson väntar folkstorm om pensionen", i Expressen Ekonomi I8 februari 2005.

URL: http://www.expressen.se/ekonomi/persson-vantar-folkstorm-om-pensionen/ (2I augusti 20I4)

Foucault, Michel (199I) "Governmentality", i Burchell, Graham, Gordon, Colin \& Miller, Peter (red.), The Foucault effect. Studies in governmentality. With two lectures by and an interview with Michel Foucault. London: Harvester Wheatsheaf.

Hacking, Ian (1990) The taming of chance. Cambridge: Cambridge University Press.

Harrysson, Lars (2000) "Tjänstepensionering före ATP: Framväxten och innebörden av oantastbara pensioner för anställda i enskild tjänst", i Arkiv för studier i arbetarrörelsens historia, $\mathrm{nr} 8 \mathrm{O}$, s. I-33.

Harrysson, Lars \& Werner, Erika (2007) "Preparing for retirement - a comparative view. Personal experiences of financial preparations from four nations", i Harrysson, Lars \& O'Brien, Michael (red.), Social welfare, social exclusion. A life course frame. Lund: Värpinge ord \& text. 
Helldén, Arne (1994) Social arrogans. Också ett kulturarv. Stockholm: Carlsson.

Hjort, Torbjörn (2004) Nödvändighetens pris. Konsumtion och knapphet bland barnfamiljer. Avhandling från Lunds universitet.

Hvinden, Bjørn \& Schøyen, Mi Ah (2013) "Sosialforsikring i Norden: En balansegang mellom holdbarhet og tilstrekkelighet. Et perspektiv fra Norge", i De första Ioo åren. Svensk välfärdspolitik mellan historia och framtid. Rapport frän forskarseminariet $i$ Umeå 16-I7 januari 2013. Socialförsäkringsrapport 2013:4 från Försäkringskassan.

ISF (2012) Enkel, detaljerad och samlad pensionsinformation. Är det möjligt? Rapport 20I2:I4 från Inspektionen för socialförsäkringen (ISF).

Kahneman, Daniel, Odean, Terrance \& Barber, Brad (2005) "Privatized pensions: an irrational choice", i Global Agenda Magazine 2005.

URL: http://faculty.gsm.ucdavis.edu/_bmbarber/Paper\%2oFolder/Global\%20 Agenda.pdf (2I augusti 20I4)

Klepke, Martin (2013) ”Nej, alla kan inte alls jobba några år till”, i Arbetet I2 april 2013. URL: http://arbetet.se/20I3/o4/I2/nej-alla-kan-inte-alls-jobba-nagra-ar-till/ (2I augusti 2OI4)

Kristersson, Ulf (20II) "Pensionsbranschen och staten har ett gemensamt ansvar", i Dagens Industri 7 september 201 .

URL: http://www.regeringen.se/sb/d/32I3/a/I74448 (2I augusti 20I4)

Liedman, Sven-Eric (200I) Ett oändligt äventyr. Om människans kunskaper. Stockholm: Bonniers.

Lindholm, Rolf H. (2013) "Ingen vill behålla pensionärsskatten”, i Göteborgs-Posten Io maj 2013 .

URL: http:/www.gp.se/nyheter/debatt/r.I66280o-ingen-vill-behallapensionarsskatten (2I augusti 20I4)

Lundberg, Urban (2003) Juvelen i kronan. Socialdemokraterna och den allmänna pensionen. Stockholm: Hjalmarson \& Högberg.

Mannelqvist, Ruth (2003) Samband i socialförsäkringen. En rättsvetenskaplig studie av sambandet mellan förmåner och avgifter $i$ socialförsäkringen. Avhandling från Umeå universitet.

Nyqvist, Anette (2008) Opening the orange envelope. Reform and responsibility in the remaking of the Swedish national pension system. Avhandling fran Stockholms universitet.

Ohlsson, Lars B. (2007) "Young at the margins of welfare. A study of immigrant youth and labour market establishment", i Harrysson, Lars \& O’Brien, Michael (red.), Social welfare, social exclusion. A life course frame. Lund: Värpinge ord \& text.

Palme, Joakim (red.) (200I) Hur blev den stora kompromissen möjlig? Politiken bakom den svenska pensionsreformen. Stockholm: Pensionsforum.

Ring, Patrick J. (2010) "Governance and governmentality: a discussion in the context of UK private pension provision", i Economy and Society, volym 39, nr 4, s. 534-550. DoI: http://dx.doi.org/I0.1080/03085147.2010.510683

Salonen, Tapio (2012) Barns ekonomiska utsatthet. Årsrapport 20I2:2 från Rädda barnen. URL: http:/www.raddabarnen.se/Documents/vad-vi-gor/sverige/samhallets-ansvar/ barnfattigdom/Barnfattigdom20I2-2-l\%C3\%A5ng.pdf (2I augusti 20I4) 
Scherman, K.G. (20I4) Pensioner på villovägar. Orsaker och lösningar. Stockholm: Jure förlag.

Sen, Amartya (1992) Inequality reexamined. New York: Russell Sage Foundation.

Sen, Amartya (200I) Etik och ekonomi. Stockholm: SNS.

Schmidt, Folke (1974) Allmänna och privata pensioner. Mål och medel. Stockholm: Norstedts.

SOU 1994:20. Reformerat pensionssystem. Betänkande av Pensionsarbetsgruppen. Stockholm: Fritze.

SOU 1997:I31. Lag om premiepension. Betänkande av 1997 års premiereservutredning. Stockholm: Fritze.

Strandberg, Love (2010) "Världens mest fondsparande folk", i Svenska Dagbladet Näringsliv II maj 20 IO.

URL: http://www.svd.se/naringsliv/nyheter/sverige/varldens-mest-fondsparande-

folk_7030797.svd (2I augusti 20I4)

Svallfors, Stefan (2003) "Välfärdsstatens legitimitet: åsikter om svensk välfärdspolitik i komparativ belysning", i Sjukskrivning - försäkring eller försörjning. Rapport frän forskarseminariet $i$ Umeå, januari 2003. Stockholm: FKF:s förlag.

Svallfors, Stefan (20II) Trygg, stöttande, tillitsfull? Svenskarnas syn på socialförsäkringarna. Underlagsrapport $\mathrm{nr} 4$ till den parlamentariska socialförsäkringsutredningen, S 20I0:04.

Werner, Erika (2012) Trygg, sviken eller osäker. Tankar och förberedelser inför pensioneringen. Avhandling från Lunds universitet.

Werner, Erika (2013) "Människors upplevelser av pensionssystem och pensionsförberedelser", i De första Ioo åren. Svensk välfärdspolitik mellan historia och framtid. Rapport från forskarseminariet $i$ Umeå I6-I7 januari 2013. Socialförsäkringsrapport 2013:4 från Försäkringskassan.

Wilkinson, Richard \& Pickett, Kate (20Iо) Jämlikhetsanden. Därför är mer jämlika sambällen nästan alltid bättre sambällen. Stockholm: Karneval. 

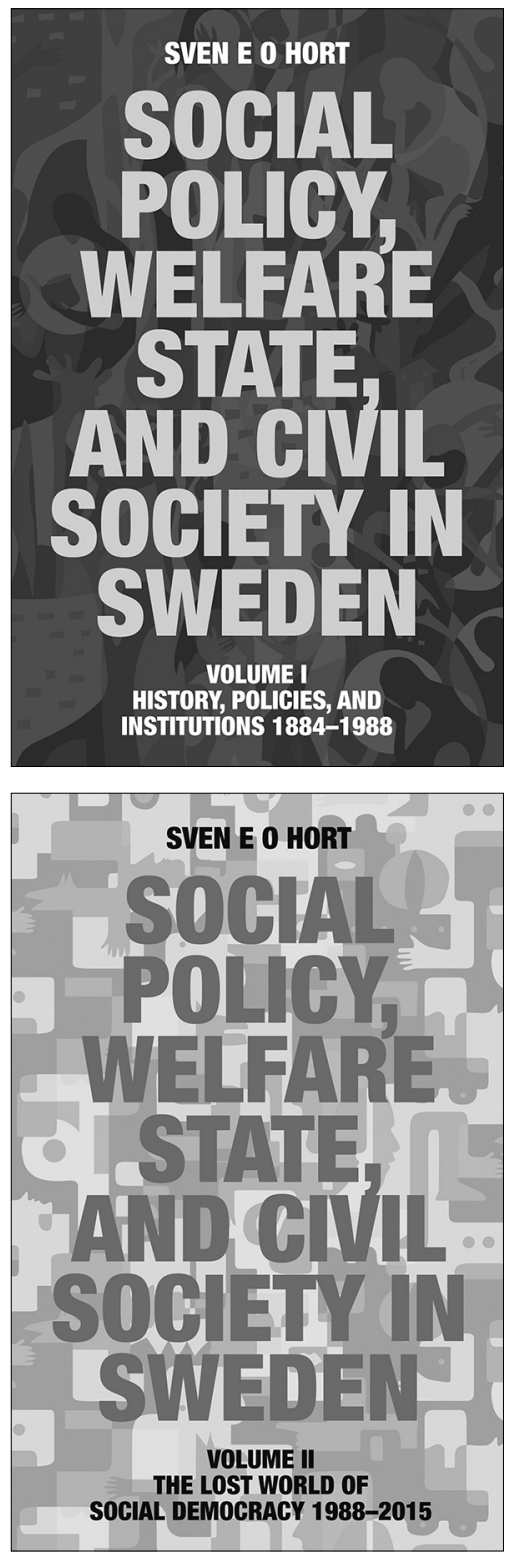

\section{SOCIAL POLICY, WELFARE STATE, AND CIVIL SOCIETY IN SWEDEN}

\author{
VOLUME | \& ||
}

\section{SVEN E 0 HORT}

Den tredje, aktualiserade och utökade upplagan i två volymer av Sven Horts inflytelserika studie av den svenska välfärdsstaten. Verket gavs ursprungligen ut 1990, under författarens dåvarande namn Sven E Olsson, som Social Policy and Welfare State in Sweden. Med den nya upplagan har boken utökats med en nyskriven volym II som handlar om de nya utmaningar som välfärdsstaten mött efter 1988 . Särskilt fokus ligger på hur den en gång så berömda svenska välfärdsstaten samtidigt nedrustats och omdanats under perioden, och utvecklingen jämförs med den i Danmark, Norge och Finland.

\section{Arkiv förlag 20I4, 2 flexband, 346 respektive 208 sidor}

